\title{
Adsorption of Indigo Carmine Dye onto Porous Adsorbent Derived from Banaba Peels Waste
}

\author{
Duangdao Channei ${ }^{1, *}$ and Panatda Jannoey ${ }^{2}$ \\ ${ }^{I}$ Department of Chemistry, Faculty of Science, Naresuan University, Phitsanulok 65000, Thailand \\ ${ }^{2}$ Department of Biochemistry, Faculty of Medical Science, Naresuan University, \\ Phitsanulok 65000, Thailand
}

('Corresponding author's e-mail: duangdaoc@nu.ac.th)

Received: 28 January 2021, Revised: 20 June 2021, Accepted: 23 June 2021

\begin{abstract}
This study investigated the preparation method and adsorption efficiency of porous adsorbents prepared from banana peels (BP) waste. The BP waste was acquired from banana fried chip factories in Sukhothai province. Chemical activation by sulfuric acid was used to activate the raw material, followed by carbonization at $500{ }^{\circ} \mathrm{C}$. The activated $\mathrm{BP}$ adsorbent has been characterized by energy dispersive $\mathrm{X}$ ray spectrometer (EDXRF), $\mathrm{N}_{2}$ adsorption-desorption isotherms (BET), scanning electron microscopy (SEM), and zeta potential measurements. The analysis of chemical properties showed that it mainly contained $70.39 \% \mathrm{~K}$ matter. The specific surface area of the BP sample reached $215.05 \mathrm{~m}^{2} / \mathrm{g}$ under acid activation and thermal treatment. The SEM images showed the morphologies of the BP adsorbent before and after activation. There was a significant change in the morphology and in the dried BP and activated BP. The $\mathrm{pH}_{\mathrm{PZC}}$ value of the activated BP obtained under optimal conditions was 4.13. Adsorption of indigo carmine (IC) onto porous activated BP at different initial IC concentrations $(10-100 \mathrm{mg} / \mathrm{L})$ and contact times $(30-120 \mathrm{~min})$ was investigated using batch experiments $(0.1 \mathrm{~g} / 50 \mathrm{~mL})$. At an optimum contact time of $60 \mathrm{~min}$, maximum adsorption capacity was determined at $56.18 \mathrm{mg} / \mathrm{g}$. The Freundlich isotherm model with a high correlation coefficient was used to describe multilayer adsorption. The kinetic study fit well with a pseudo second-order kinetic model that represented chemisorption. The negative $\Delta \mathrm{G}^{\circ}$ value of $-14.64 \mathrm{~kJ} / \mathrm{mol}$ indicated that adsorption of IC onto the BP adsorbent was spontaneous in nature at $305.15 \mathrm{~K}$.
\end{abstract}

Keywords: Adsorbent, Adsorption isotherm, Adsorption kinetics, Banana peels, Indigo carmine

\section{Introduction}

Textile dye contamination in wastewater is of major environmental concern. These highly colored toxic carcinogenic substances severely impact both human health and aquatic life. Rhodamine B, methyl orange, methylene blue, acid orange7, and indigo carmine (IC) are released into the environment as untreated waste from various textile industry activities such as dyeing, washing, and removing [1,2]. Textile dyes at only $1 \mathrm{mg} / \mathrm{L}$ can impact photosynthesis in aquatic plants by blocking light penetration into the water, resulting in growth impairment [3]. Since the chemical structure of the dye molecule is represented by a backbone of the complex aromatic molecular structures that are toxic, thus it makes it a difficult threat. The example of azo dyes with structures containing aromatic groups is represented in Figure 1.<smiles>O=C1/C(=C2\Nc3ccc(S(=O)(=O)[O-])cc3C2=O)Nc2ccc(S(=O)(=O)[O-])cc21</smiles>

Figure 1 Structural formula for indigo carmine (IC) [4]. 
Several methods have been trialed to treat wastewater containing dyes before discharge to the natural environment, such as coagulation, precipitation, electrochemical degradation, ion exchange, and adsorption [5-7]. Among these, adsorption has been widely used to remove organic/inorganic compounds as this method is easy to operate with high efficiency and is also cost effective. Most common adsorbents contain activated carbon that has a high surface area and porosity. However, activated carbon is very expensive and in high demand. Recently, research into low-cost adsorbents as alternatives to activated carbon has increased. Agricultural waste materials show promise as highly porous adsorbents. Adsorption capacities of tea waste, corncob, rice husk, lignin-chitosan, sugarcane bagasse, zeolite, wood charcoal, and sawdust [8-15] for removal of various types of pollutants are listed in Table 1.

Table 1 Comparison of the adsorption capacity of the other reported adsorbents.

\begin{tabular}{cccc}
\hline Adsorbent & Type of pollutant & Maximum capacity (mg/g) & Reference \\
\hline Tea waste & Carbofuran & 10.20 & {$[8]$} \\
Corncob & Methylene blue & 17.57 & {$[9]$} \\
Rice husk & Cd(II) & 28.27 & {$[10]$} \\
Lignin-chitosan & Methylene blue & 36.25 & {$[11]$} \\
Sugarcane bagasse & Pb(II) & 50.00 & {$[12]$} \\
Zeolite & Etheramine & 80.80 & {$[13]$} \\
Wood charcoal & Bentazon & 169.49 & {$[14]$} \\
Saw dust & 17.57 & 81.00 & {$[15]$} \\
\hline
\end{tabular}

Banana peel (BP) waste is one of the most widely available agricultural wastes from banana fried chip factories in Sukhothai Province, especially in Kong Krailat district. Therefore, this study aimed to enhance and increase the value of banana peel waste, instead of dumping it in open areas. The efficiency of the porous adsorbent derived from BP residue for removal of IC from aqueous solution was investigated. The effects of the initial concentration of IC solution and contact time on adsorption were studied. Equilibrium isotherms, kinetic experiments and thermodynamic studies were also compared and discussed.

\section{Materials and methods}

\section{Preparation of porous adsorbent derived from banana peel (BP) waste}

About 1,000 g of BP waste was collected from banana fried chip factories in Kong Krailat district, Sukhothai Province, Thailand. To remove moisture, BP samples were cut, washed, and dried in a hot-air oven at $120^{\circ} \mathrm{C}$ for $24 \mathrm{~h}$. Dried BP was impregnated with $6 \mathrm{M} \mathrm{H} 2 \mathrm{SO} 4$ for $24 \mathrm{~h}$ to increase porosity (100 g BP: $1,000 \mathrm{~L}$ acid). The impregnated BP was carbonized in a muffle furnace at $500{ }^{\circ} \mathrm{C}$ for $1 \mathrm{~h}$. The black powder produced was collected and stored in a desiccator to avoid moisture absorption.

\section{Indigo carmine dye solution}

A stock solution of IC with an initial concentration of $100 \mathrm{mg} / \mathrm{L}$ was prepared by dissolving IC powder in DI water. About $60 \mathrm{~mL}$ of IC stock solution was diluted with $100 \mathrm{~mL}$ of DI (60 mg/L). A series of IC concentrations in the range of 20 and $10 \mathrm{mg} / \mathrm{L}$ were prepared by transferring 20 and $10 \mathrm{~mL}$ of IC dye stock solution and diluting them up to $100 \mathrm{~mL}$ with DI water. The $\mathrm{pH}$ of the natural IC dye solution was about 9 for the initial concentration, and this was adjusted to $\mathrm{pH} 3$ with the addition of $1 \mathrm{M} \mathrm{HCl}$ solution to render favorable electrostatic attraction between the IC dye and the BP adsorbent.

\section{Characterization}

The surface morphology of the BP adsorbent was analyzed using a field-emission scanning electron microscope (FE-SEM: JSM 6335). Specific surface areas associated with hysteresis loops were recorded by the $\mathrm{N}_{2}$ adsorption/desorption isotherm based on the theory of Brunauer-Emmett-Teller (BET, Micromeritics TriStar II 3020). The surface charge of the BP adsorbent was characterized by zeta potential measurements (Malvern Zetasizer $\left.{ }^{\circledR}\right)$. The elemental analysis of BP adsorbent ash was analyzed by an Energy Dispersive X-Ray Spectrometer (EDXRF, HORIBA MESA-500W). 


\section{Batch adsorption experiments}

Batch adsorption experiments were performed to study the capacity of BP adsorbent for IC adsorption by mixing $0.1 \mathrm{~g}$ of BP adsorbent powders with $50 \mathrm{~mL}$ IC solution of known initial concentration $(10,20,60$ and $100 \mathrm{mg} / \mathrm{L})$. The suspension was shaken every $30 \mathrm{~min}$ with an agitation speed of $250 \mathrm{rpm}(0,30,60,90$ and $120 \mathrm{~min})$. The IC supernatant was separated from the suspension by centrifugation. The gradual decrease in IC concentration as well as the decrease in absorbance intensity were estimated using a UV/VIS Spectrophotometer (Shanghai Mapada Instruments Co., Ltd.) at a fixed wavelength of $615 \mathrm{~nm}$.

\section{Results and discussion}

\section{Material characterizations}

Elemental analysis of dried BP was determined by EDXRF analysis as shown in Table 2. Results revealed that dried $\mathrm{BP}$ mainly contained $\mathrm{K}, \mathrm{Ca}$ and $\mathrm{Si}$ with traces of other metal elements. The $\mathrm{K}$ matter was present in large quantities because BP is normally a rich source of K. However, analysis of light elements like carbon content cannot be quantified by the EDXRF method.

Table 2 Elemental analysis of dried BP by EDXRF.

\begin{tabular}{cccc}
\hline Component & \% w/w & Component & \% w/w \\
\hline $\mathrm{K}$ & 70.39 & $\mathrm{~S}$ & 0.97 \\
$\mathrm{Ca}$ & 19.97 & $\mathrm{Mn}$ & 0.48 \\
$\mathrm{Si}$ & 2.35 & $\mathrm{Zn}$ & 0.38 \\
$\mathrm{Fe}$ & 1.84 & $\mathrm{Rb}$ & 0.37 \\
$\mathrm{Ti}$ & 1.55 & $\mathrm{Sr}$ & 0.29 \\
$\mathrm{P}$ & 1.40 & & \\
\hline
\end{tabular}

The surface morphology of BP before and after carbonization was studied by FE-SEM as shown in Figures 2. Surface morphology and pore texture of the adsorbent are significant factors affecting adsorption, thus BP adsorbent produced by acid activation and carbonization was expected to adsorb IC with better adsorption capacity. The micrographs showed changes in surface texture of BP adsorbents after acid activation and carbonization at high temperature, producing a porous structure with high surface area of BP adsorbent. Chemical activation by activating agents such as $\mathrm{H}_{2} \mathrm{SO}_{4}$ develops pore network generation. Following heat treatment at $500{ }^{\circ} \mathrm{C}$, BP raw materials were converted to carbon by reducing ash content, yielding high carbon content in terms of adsorption capacity [16].

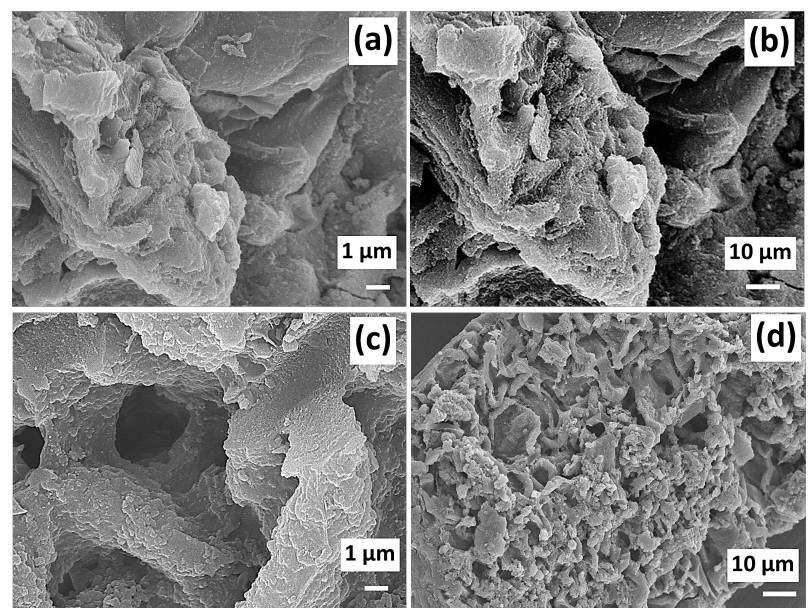

Figure 2 FE-SEM images of (a), (b) Dried BP and (c), (d) Activated BP adsorbent. 

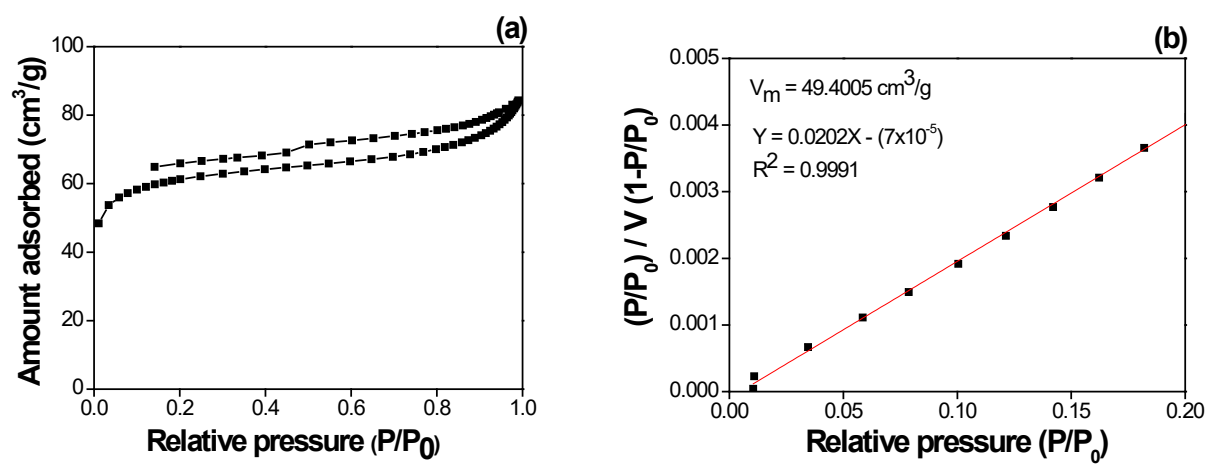

Figure 3 (a) Hysteresis of adsorption/desorption of $\mathrm{N}_{2}$ and (b) Linear fitted BET-surface area.

Table 3 Surface properties of the activated BP adsorbent.

\begin{tabular}{ccc}
\hline $\begin{array}{c}\text { BET specific surface area } \\
\left(\mathbf{m}^{\mathbf{2}} / \mathbf{g}\right)\end{array}$ & $\begin{array}{c}\text { Pore volume } \\
\left(\mathbf{c m}^{\mathbf{3}} / \mathbf{g}\right)\end{array}$ & $\begin{array}{c}\text { Pore size } \\
(\mathbf{n m})\end{array}$ \\
\hline 215.05 & 0.05 & 5.78 \\
\hline
\end{tabular}

Figure 3(a) shows the $\mathrm{N}_{2}$ adsorption/desorption isotherm and BET linear plot of the BP adsorbent after activation. The hysteresis phenomenon is usually associated with capillary condensation in mesopore structures $(2-50 \mathrm{~nm})$, related to an average pore size diameter of $5.78 \mathrm{~nm}$, as listed in Table 3 . Furthermore, the pore shown here does not agree well with the 1 attributed to the SEM images. This can be attributed to the fact that SEM images are collected over a selected area of the surface of the sample. In the case of BET average pore size diameter, there is a distribution in pore size that relates to micropores, mesopores, and macropores. In addition, the hysteresis loop belonged to the type- $\mathrm{H} 3$ that is often attributed to narrow slit-shaped pores according to the IUPAC classification of hysteresis, commonly found in physical adsorption of gases (i.e., $\mathrm{N}_{2}$ ) onto porous adsorbent [17]. The linear plot in Figure 3(b) was produced by the following equations [18,19];

$\frac{\mathrm{P} / \mathrm{P}_{0}}{\mathrm{~V}\left(1-\mathrm{P} / \mathrm{P}_{0}\right)}=\frac{1}{\mathrm{~V}_{\mathrm{m}} \mathrm{C}}+\frac{(\mathrm{C}-1)}{\mathrm{V}_{\mathrm{m}} \mathrm{C}} \frac{\mathrm{P}}{\mathrm{P}_{0}}$

where, $\mathrm{P}_{0}=$ Initial pressure of $\mathrm{N}_{2}$,

$\mathrm{P}=$ Equilibrium pressure of $\mathrm{N}_{2}$ adsorption,

$\mathrm{V}=$ Amount of adsorbed $\mathrm{N}_{2}$,

$\mathrm{V}_{\mathrm{m}}=$ Volume of monolayer adsorption,

$\mathrm{C}=\mathrm{BET}$ constant.

With known intercept and slope from the linear regression, the value for $\mathrm{V}_{\mathrm{m}}$ obtained from the slope was $49.4005 \mathrm{~cm}^{3} / \mathrm{g}$. The following equation describes the method for BET-specific surface area (SSA) calculation via the $\mathrm{V}_{\mathrm{m}}$ parameter and the cross-sectional area of adsorbed gas. Based on the equation below, the calculated SSA of BP adsorbent was about $215.05 \mathrm{~m}^{2} / \mathrm{g}$;

Specific surface area $=\frac{\mathrm{A} \times \mathrm{V}_{\mathrm{m}} \times \mathrm{N}_{\mathrm{a}}}{\mathrm{m} \times 22400}$

where, $A=$ Cross-sectional areas of adsorbed $\mathrm{N}_{2}\left(1.62 \times 10^{-15} \mathrm{~cm}^{2}\right)[20]$,

$\mathrm{N}_{\mathrm{a}}=$ Avogadro's constant $\left(6.022 \times 10^{23}\right.$ atom $\left./ \mathrm{mol}\right)$,

$\mathrm{m}=$ Mass of BP adsorbent $(1 \mathrm{~g})$.

Zeta potentials of BP adsorbent after activation as a function of solution $\mathrm{pH}(2-12)$ are shown in Figure 4. The point of zero charge (PZC) is normally represented by the $\mathrm{pH}$ at which the surface charge is equal to zero [21], thus $\mathrm{pH} 4.13$ was determined as PZC of BP adsorbent. Decreasing pH below 4.13 
made the surface of BP adsorbent positive. For anionic dye pollutants like IC (Figure 1), favorable adsorption of BP adsorbent and IC should occur below the PZC point ( $\mathrm{pH}<\mathrm{PZC})$. The $\mathrm{pH}$ value for IC in this study was adjusted to 3 as favorable for adsorption between negatively charged IC and the positive charge of BP adsorbent.

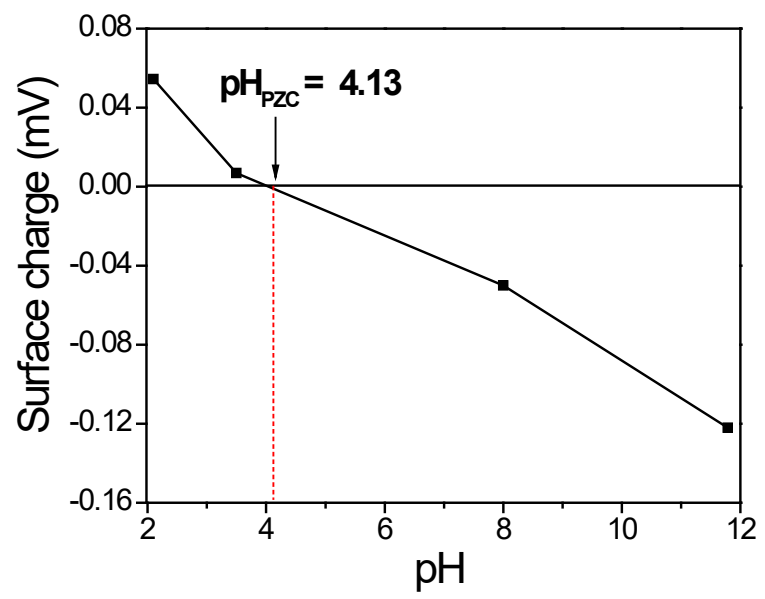

Figure 4 Point of zero charge of BP adsorbent.

\section{Adsorption equilibrium}

The initial concentration of IC $\left(\mathrm{C}_{0}\right)$ was varied between 10, 20, 60 and $100 \mathrm{mg} / \mathrm{L}$. After adsorption at different time intervals $(0,30,60,90$ and $120 \mathrm{~min})$, the remaining concentrations of IC at different time intervals $\left(\mathrm{C}_{t}\right)$ were calculated from the slope of the calibration curve, as shown in Figure 5(a).

Figure 5(b) shows that IC adsorption decreased sharply during the initial stage of adsorption and then the concentration slowly decreased with time, becoming constant after $60 \mathrm{~min}$. This was attributed to the active sites during the first stage of adsorption that were still available. An increase in contact time as well as increased IC concentration made the remaining sites per unit mass of BP adsorbent more difficult to access, thus restricting the adsorption process.

The amounts of IC adsorbed on BP adsorbent (qt) and adsorbate adsorbed at equilibrium (qe) in Figure 5(c) were calculated using the following equations [22];

$$
\begin{aligned}
& q_{t}=\frac{\left(C_{0}-C_{t}\right) V}{W} \\
& q_{e}=\frac{\left(C_{0}-C_{e}\right) V}{W}
\end{aligned}
$$

where, $q_{t}=$ Amount of IC adsorbed on BP adsorbent at different time intervals $(\mathrm{mg} / \mathrm{g})$,

$q_{e}=$ Amount of IC adsorbed at equilibrium $(\mathrm{mg} / \mathrm{g})$,

$C_{0}=$ Initial concentration of IC solution $(\mathrm{mg} / \mathrm{L})$,

$C_{t}=$ Residual concentration of IC calculated from the calibration curve $(\mathrm{mg} / \mathrm{L})$,

$C_{e}=$ Equilibrium concentrations of IC $(\mathrm{mg} / \mathrm{L})$,

$V=$ Volume of IC solution (L),

$W=$ Amount of BP adsorbent (g).

For $\mathrm{C}_{\mathrm{e}}$ and $\mathrm{q}_{\mathrm{e}}$ parameters, they were obtained from plotting the graph for $\mathrm{C}_{\mathrm{t}}$ and $\mathrm{q}_{\mathrm{t}}$ against time. Thus, based on equilibrium at $60 \mathrm{~min}, \mathrm{C}_{\mathrm{e}}$ values were $7.79,15.76,48.72$ and 76.14 , while $\mathrm{q}_{\mathrm{e}}$ values were $1.39,2.74,5.46$ and 12.58 for IC concentration of $10,20,60$ and $100 \mathrm{mg} / \mathrm{L}$, respectively. The parameters $\mathrm{C}_{\mathrm{e}}$ and $\mathrm{q}_{\mathrm{e}}$ were further used to calculate adsorption isotherms, kinetics and thermodynamics of the process. 

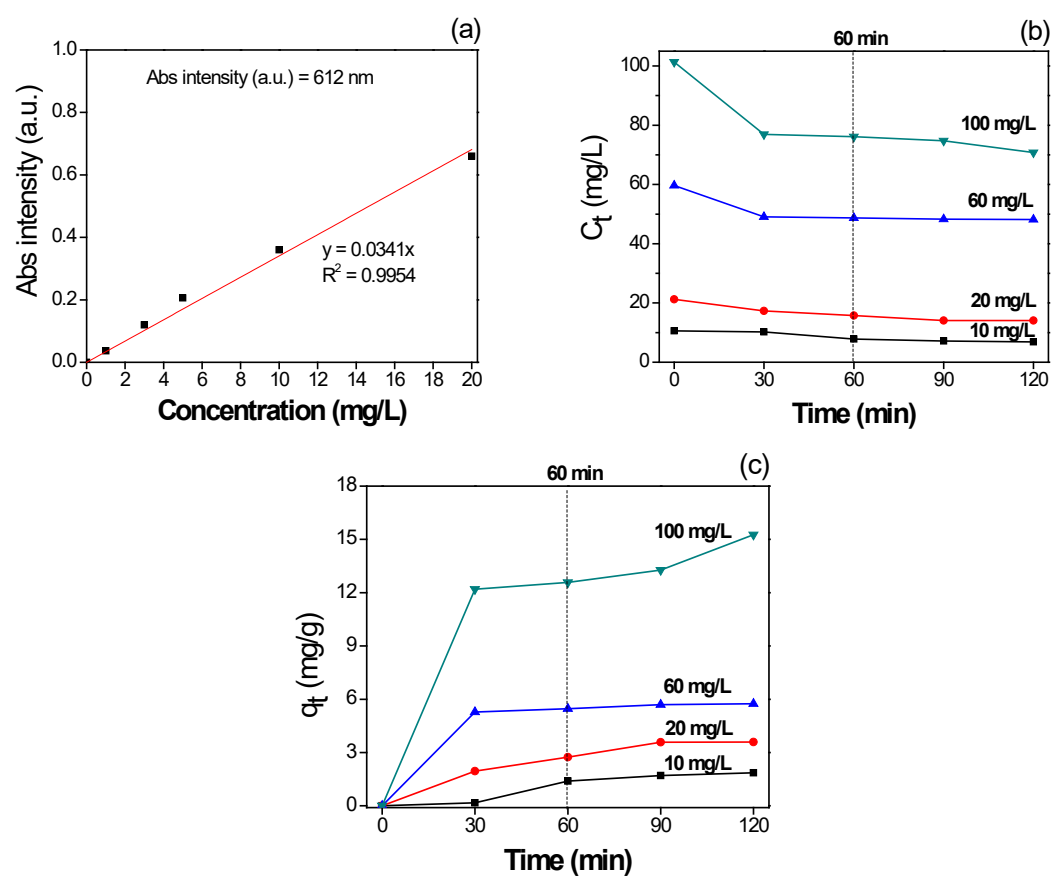

Figure 5 (a) Calibration curve, (b) $\mathrm{C}_{\mathrm{t}}$ and (c) $\mathrm{q}_{\mathrm{t}}$.

\section{Adsorption isotherms}

To study the adsorption behavior between the BP adsorbent and the IC adsorbate, the linear form of the Langmuir and Freundlich models are given by the following equations, respectively [23].

$$
\begin{aligned}
& \frac{C_{e}}{q_{e}}=\frac{C_{e}}{q_{m}}+\frac{1}{K_{L} q_{m}} \\
& \log q_{e}=\frac{1}{n} \log C_{e}+\log K_{F}
\end{aligned}
$$

When comparing the graph plots between Figures 6(a) and 6(b), the Freundlich model showed a better fit to the adsorption data than the Langmuir model due to the higher correlation coefficient $\left(\mathrm{R}^{2}\right)$ that involved multilayer adsorption. As shown in Table 4, the 1/n value of 0.8887 obtained from the slope of the Freundlich plot was greater than 0.5 , indicating favorable multilayer adsorption on heterogeneous surfaces [24].

(a)

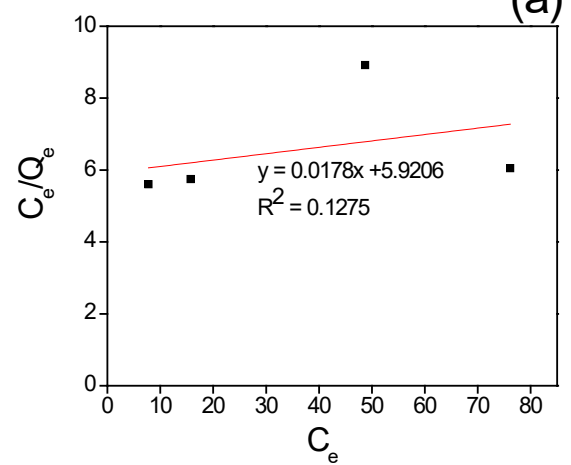

(b)

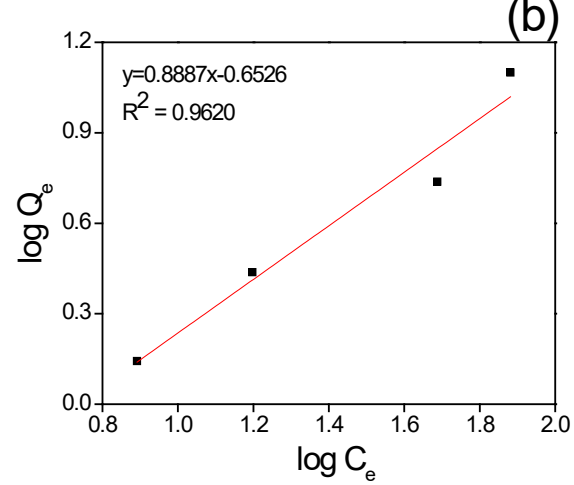

Figure 6 (a) Langmuir and (b) Freundlich models. 
Table 4 Equilibrium parameters for IC adsorption.

\begin{tabular}{cccc}
\hline & $\mathbf{R}^{2}$ & \multicolumn{2}{c}{ Parameters } \\
\hline \multirow{2}{*}{ Langmuir } & \multirow{2}{*}{0.1275} & $\mathrm{q}_{\mathrm{m}}$ & $56.18 \mathrm{mg} / \mathrm{g}$ \\
& & Langmuir constant $\left(\mathrm{K}_{\mathrm{L}}\right)$ & 0.0030 \\
\hline \multirow{2}{*}{ Freundlich } & \multirow{2}{*}{0.9620} & $1 / \mathrm{n}$ & 0.8887 \\
& & Freundlich constant $\left(\mathrm{K}_{\mathrm{F}}\right)$ & 0.2225 \\
\hline
\end{tabular}

Table 5 Comparison of $\mathrm{q}_{\mathrm{m}}$ value of various adsorbent for IC adsorption.

\begin{tabular}{ccc}
\hline Adsorbent & $\mathbf{q}_{\mathbf{m}}(\mathbf{m g} / \mathbf{g})$ & Reference \\
\hline BP adsorbent & 56.18 & This study \\
Calcium hydroxide & 0.95 & {$[25]$} \\
Thapsia transtagana (plant) & 44.87 & {$[26]$} \\
Red mud & 62.60 & {$[27]$} \\
Commercial activated carbon & 79.49 & {$[28]$} \\
\hline
\end{tabular}

Table 5 compares IC maximum adsorption capacities $\left(\mathrm{q}_{\mathrm{m}}\right)$ with different adsorbents reported in the literature [25-28]. The BP adsorbent synthesized here revealed high potential in comparison with the other adsorbents. A high capacity $\mathrm{q}_{\mathrm{m}}$ value of $56.18 \mathrm{mg} / \mathrm{g}$ is still acceptable when considering banana peel as adsorbent. However, the effectiveness of each adsorbent depended on a well-developed porous structure and the surface chemistry.

\section{Kinetic experiments}

The linear equations given below describe the pseudo first-order and pseudo second-order equations, respectively [29];

$$
\begin{aligned}
& \log \left(q_{e}-q_{t}\right)=-\frac{k_{1}}{2.303} t+\log q_{e} \\
& \frac{t}{q_{t}}=\frac{1}{q_{e}} t+\frac{1}{k_{2} q_{e}^{2}}
\end{aligned}
$$

(a)

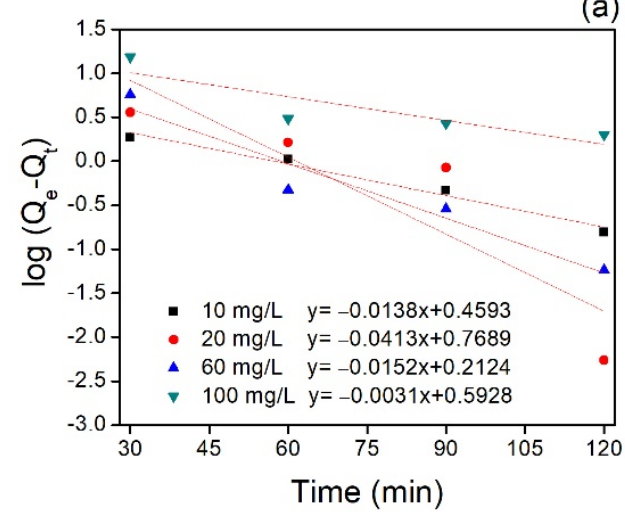

(b)

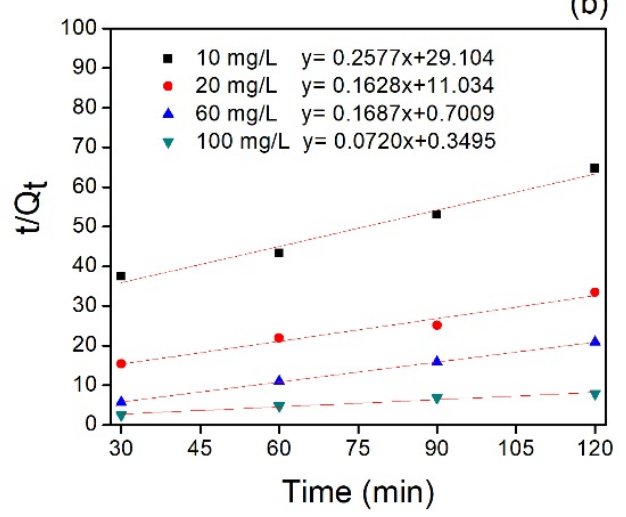

Figure 7 (a) Pseudo first-order and (b) Pseudo second-order plots.

As shown in Figure 7, kinetic data from pseudo first-order and pseudo second-order models were plotted. All kinetic constants, including $\mathrm{q}_{\mathrm{e}(\mathrm{exp})}$, $\mathrm{q}_{\mathrm{e}}$ (cal) and $\mathrm{R}^{2}$ obtained from the regression equation for the linear plot are summarized in Table 6. The $\mathrm{q}_{\mathrm{e}}$ values obtained from the experiments, $\mathrm{q}_{\mathrm{e}(\mathrm{exp}) \text {, did not follow }}$ 
a pseudo first-order kinetic model due to differences between the calculation values of $\mathrm{q}_{\mathrm{e}}$ (cal) and $\mathrm{q}_{\mathrm{e}(\mathrm{exp}) \text {, }}$ while $\mathrm{R}^{2}$ values extracted from the straight lines of this model were not close to 1 . On the other hand, the

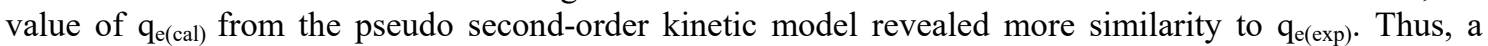
pseudo second-order kinetic model involving chemical adsorption between the 2 phases can adequately explain the adsorption of IC onto BP adsorbent.

Table 6 Kinetic parameters for adsorption of IC onto BP adsorbent.

\begin{tabular}{|c|c|c|c|c|c|}
\hline \multirow{2}{*}{$\begin{array}{c}\mathrm{C}_{0} \\
(\mathrm{mg} / \mathrm{L})\end{array}$} & \multirow{2}{*}{$\begin{array}{c}\mathrm{q}_{\mathrm{e}(\mathrm{exp})} \\
(\mathrm{mg} / \mathrm{g})\end{array}$} & \multicolumn{2}{|c|}{ Pseudo $1^{\text {st }}$-order } & \multicolumn{2}{|c|}{ Pseudo $2^{\text {nd }}$-order } \\
\hline & & $\mathbf{R}^{2}$ & $\mathbf{q}_{\text {e(cal) }}$ & $\mathbf{R}^{2}$ & $\mathbf{q}_{\mathrm{e}(\mathrm{cal})}$ \\
\hline 10 & 1.39 & 0.9782 & 2.88 & 0.9927 & 3.88 \\
\hline 20 & 2.74 & 0.8354 & 5.87 & 0.9639 & 6.14 \\
\hline 60 & 5.46 & 0.9164 & 1.63 & 0.9993 & 5.93 \\
\hline 100 & 12.58 & 0.9558 & 3.92 & 0.9984 & 13.89 \\
\hline
\end{tabular}

\section{Thermodynamic experiments}

Thermodynamic parameters such as the change in Gibb's free energy $\left(\Delta \mathrm{G}^{0}\right)$ were used to explain the variation in dye removal efficiency with temperature. In this study, $\Delta \mathrm{G}^{0}$ for IC adsorption in acidic $\mathrm{pH} 3$ at $305.15 \mathrm{~K}\left(32.0^{\circ} \mathrm{C}\right)$ was evaluated using the relationship between $\Delta \mathrm{G}^{\circ}$ and the Langmuir constant $\left(\mathrm{K}_{\mathrm{L}}\right)$ of $0.0030 \mathrm{~L} / \mathrm{g}$, as shown in the following equation [30];

$-\Delta \mathrm{G}^{\mathrm{o}}=\mathrm{RT} \ln \mathrm{K}_{\mathrm{L}} \quad(\mathrm{R}=8.314 \mathrm{~J} / \mathrm{mol} . \mathrm{K})$

The negative value of $\Delta \mathrm{G}^{\circ}(-14.64 \mathrm{~kJ} / \mathrm{mol})$ corresponded to a spontaneous process at a given temperature, thus favoring adsorption of IC dye with a reversible reaction that was in mutual thermodynamic equilibrium under experimental conditions.

\section{Conclusions}

Adsorption of IC on the highly specific surface area of banana peel (BP) adsorbent $\left(215.05 \mathrm{~m}^{2} / \mathrm{g}\right)$ was measured in a batch experiment. Optimum conditions for the adsorption of IC on BP adsorbent were determined by analyzing various adsorption conditions, including contact time of adsorption ( 0 - $120 \mathrm{~min})$ and initial IC concentration $(10-100 \mathrm{mg} / \mathrm{L})$ with fixed $\mathrm{pH}$ of all IC solutions at 3 . Results revealed that multilayer adsorption related to the Freundlich model fitted better with the experimental results compared to the Langmuir model. Maximum adsorption capacity obtained from the slope of the Langmuir plot was $56.18 \mathrm{mg} / \mathrm{g}$ and offered great potential for removing pollutants from wastewater. Kinetic studies obeyed a pseudo second-order equation with chemical adsorption between IC and BP adsorbent. Results were confirmed by the very close agreement of experimental $\mathrm{q}_{\mathrm{e}}$ values and calculated $\mathrm{q}_{\mathrm{e}}$ values. The negative $\Delta \mathrm{G}^{\circ}$ value indicated that the spontaneous nature of the adsorption process was favorable at a given temperature. This study not only reports an alternative method for removing toxic organic pollutants from water, but it also adds value to banana peel waste.

\section{Acknowledgements}

The authors would like to thank the "National Science, Research, and Innovation Fund (NSRF)" under grant number R2563B001 for providing the financial support throughout this work.

\section{References}

[1] Z Harrache, M Abbas, T Aksil and M Trari. Thermodynamic and kinetics studies on adsorption of Indigo Carmine from aqueous solution by activated carbon. Microchem J. 2019; 144, 180-9.

[2] HR Rashidi, NM Sulaiman and NA Hashim. Batik industry synthetic waste treatment using nanofiltration membrane. Proc. Eng. 2012; 44, 2010-2.

[3] A Kume. Importance of the green color, absorption gradient, and spectral absorption of chloroplasts for the radiative energy balance of leaves. J. Plant Res. 2017; 130, 501-14.

[4] MI Abdullah, MRSA Janjua, A Mahmood, S Ali and M Ali. Quantum chemical designing of efficient sensitizers for dye sensitized solar cells. Bull. Kor. Chem. Soc. 2013; 34, 2093-8. 
[5] RE Palma-Goyes, J Silva-Agredo, I González and RA Torres-Palma. Comparative degradation of indigo carmine by electrochemical oxidation and advanced oxidation processes. Electrochim. Acta 2014; 140, 427-33.

[6] AY Zahrim and N Hilal. Treatment of highly concentrated dye solution by coagulation/flocculationsand filtration and nanofiltration. Water Resour. Ind. 2013; 3, 23-34.

[7] GZ Kyzas, J Fu and KA Matis. The change from past to future for adsorbent materials in treatment of dyeing wastewaters. Materials 2013; 6, 5131-58.

[8] M Vithanage, SS Mayakaduwa, I Herath, YS Ok and D Mohan. Kinetics, thermodynamics and mechanistic studies of carbofuran removal using biochars from tea waste and rice husks. Chemosphere 2016; 150, 781-9.

[9] GO El-Sayed, MM Yehia and AA Asaad. Assessment of activated carbon prepared from corncob by chemical activation with phosphoric acid. Water Resour. Ind. 2014; 7-8, 66-75.

[10] MC Hoyos-Sánchez, AC Córdoba-Pacheco, LF Rodríguez-Herrera and R Uribe-Kaffur . Removal of Cd (II) from aqueous media by adsorption onto chemically and thermally treated rice husk. $J$. Chem. 2017; 2017, 5763832.

[11] AB Albadarin, MN Collins, M Naushad, S Shirazian, G Walker and C Mangwandi. Activated lignin-chitosan extruded blends for efficient adsorption of methylene blue. Chem. Eng. J. 2017; 307, 264-72.

[12] HC Tao, HR Zhang, JR Li and WY Ding. Biomass based activated carbon obtained from sludge and sugarcane bagasse for removing lead ion from wastewater. Bioresour. Tech. 2015; 192, 611-7.

[13] ZM Magriotis, PVB Lea, PFD Sales, RM Papini, PRM Vian and PA Arroyo. A comparative study for the removal of mining wastewater by kaolinite, activated carbon and beta zeolite. Appl. Clay Sci. 2014; 91-92, 55-62.

[14] A Omri, A Wali and M Benzina. Adsorption of bentazon on activated carbon prepared from Lawsonia inermis wood: Equilibrium, kinetic and thermodynamic studies. Arab. J. Chem. 2016; 9, S1729-S1739.

[15] GM Couto, AL Dessimoni, ML Bianchi, DM Perígolo and PF Trugilho. Use of sawdust Eucalyptus sp. in the preparation of activated carbons. Ciência e Agrotecnologia 2012; 36, 69-77.

[16] Z Heidarinejad, MH Dehghani, M Heidari, G Javedan, I Ali and M Sillanpää. Methods for preparation and activation of activated carbon: A review. Environ. Chem. Lett. 2020; 18, 393-415.

[17] L Qi, X Tang, Z Wang, and X Peng. Pore characterization of different types of coal from coal and gas outburst disaster sites using low temperature nitrogen adsorption approach. Int. J. Min. Sci. Tech. 2017; 27, 371-7.

[18] P Iacomi and P Llewellyn. pyGAPS: A python-based framework for adsorption isotherm processing and material characterisation. Adsorption 2019; 25, 1533-49.

[19] D Eisenberg, P Prinsen, NJ Geels, W Stroek, N Yana, B Hua JL Luo and G Rothenberg. The evolution of hierarchical porosity in self-templated nitrogen-doped carbons and its effect on oxygen reduction electrocatalysis. $R S C A d v$. 2016; 6, 80398-407.

[20] D Channei, A Nakaruk, W Khanitchaidecha, P Jannoey and S Phanichphant. Equilibrium, kinetics, and thermodynamic studies concerning the removal of 2-chlorophenol using chemically carbonized rice husk waste. Naresuan Univ. Sci. Tech. 2020; 28, 94-104.

[21] S Phanichphant, A Nakaruk and D Channei. Photocatalytic activity of the binary composite $\mathrm{CeO}_{2} / \mathrm{SiO}_{2}$ for degradation of dye. Appl. Surf. Sci. 2016; 387, 214-20.

[22] AM Aljeboree, AN Alshirifi and AF Alkaim. Kinetics and equilibrium study for the adsorption of textile dyes on coconut shell activated carbon. Arab. J. Chem. 2017; 10, S3381-S3393.

[23] DAH Hanaor, M Ghadiri, W Chrzanowski and Y Gan. Scalable surface area characterization by electrokinetic analysis of complex anion Aadsorption. Langmuir 2014; 30, 15143-52.

[24] HD Utomo, XC Ong, SMS Lim, GCB Ong and P Li. Thermally processed sewage sludge for methylene blue uptake. Int. Biodeterior. Biodegrad. 2013; 85, 460-5.

[25] TN Ramesh, DV Kirana, A Ashwini and TR Manasa. Calcium hydroxide as low cost adsorbent for the effective removal of indigo carmine dye in water. J. Saudi Chem. Soc. 2017; 21, 165-71.

[26] A Machrouhi, H Alilou, M Farnane, SE Hamidi, M Sadiq, M Abdennouri, H Tounsadi and N Barka. Statistical optimization of activated carbon from Thapsia transtagana stems and dyes removal efficiency using central composite design. J. Sci. Adv. Mater. Dev. 2019; 4, 544-53.

[27] AN Babu, DS Reddy, P Sharma, GS Kumar, K Ravindhranath and GVK Mohan. Removal of hazardous indigo carmine dye from waste water using treated red mud. Mater. Today. Proc. 2019; 17, 198-208. 
[28] Z Harrache, M Abbas, T Aksil and M Trari. Thermodynamic and kinetics studies on adsorption of Indigo Carmine from aqueous solution by activated carbon. Microchem. J. 2019; 144, 180-9.

[29] PS Kumar, S Ramalingam, SD Kirupha, A Murugesan, T Vidhyadevi and S Sivanesan. Adsorption behavior of nickel (II) onto cashew nut shell: Equilibrium, thermodynamics, kinetics, mechanism and process design. Chem. Eng. J. 2011; 167, 122-31.

[30] Z Sun, Z Wu and D Liu. Microwave-assisted modification of activated carbon with cationic surfactants for enhancement of naphthalene adsorption. Kor. J. Chem. Eng. 2018; 35, 557-66. 